\title{
The Effect of Ethanol Extract of Katuk Leaves (Sauropus androgynus) on Red Blood Cell Count (HR), Hemoglobin (Hb), and Hematocrit (Ht) of Rats Exposed to Emission
}

\section{Budi Siswanto*}

\section{Budi Siswanto*}

Medical Laboratory Technology Department, Health Polytechnic of Banten, INDONESIA.

\section{Correspondence}

\section{Budi Siswanto}

Medical Laboratory Technology

Department, Health Polytechnic of Banten INDONESIA.

E-mail: budisiswanto2206@gmail.com History

- Submission Date: 11-02-2021;

- Review completed: 27-02-2021;

- Accepted Date: 12-03-2021.

DOI : 10.5530/pj.2021.13.110

Article Available online

http://www.phcogj.com/v13/i4

\section{Copyright}

(C) 2021 Phcogj.Com. This is an openaccess article distributed under the terms of the Creative Commons Attribution 4.0 International license.

\begin{abstract}
The World Health Organization (WHO) estimates that $70 \%$ of the world's urban population has breathed polluted air from motorcycle emissions. Lead poisoning will have an impact on anemia which is characterized by a decrease in the amount of red blood cell count (RBC), hemoglobin level $(\mathrm{Hb})$, and hematocrit level $(\mathrm{Ht})$. Katuk leaves contain papaverine which can bind to the red blood cell. The purpose of this research is to see the ability of the ethanol extract of katuk leaves (Sauropus androgynus) to prevent the reduction of $\mathrm{RBC}, \mathrm{Hb}$, and $\mathrm{Ht}$. The descriptive, experimental research method that analyzes changes in hematological parameters in experimental rats was conducted 24 days with samples of 30 white rats species of Rattus norvegicus, divided into five groups: control (-), control (+), Treatment 1 (P1, extract $50 \mathrm{mg} / \mathrm{kg}$ body weight), Treatment 2 (P2, extract $100 \mathrm{mg} / \mathrm{kg}$ body weight), and Treatment 3 (P3, extract $200 \mathrm{mg} / \mathrm{kg}$ body weight). All rats used in treatment groups were exposed to motorcycle smoke. The study was carried out for 16 days, and on day-17, all groups were drawn blood through the orbital vein. The results showed the concentration of extract of $200 \mathrm{mg} / \mathrm{kg}$ weight has the highest increase in hematological parameters for RBC (8.42 \pm 0.67$) ; \mathrm{Hb}(14.0$ $\pm 0.48)$; and $\mathrm{Ht}(44.6 \pm 0.89)$. Katuk leaf ethanol extract had a significant effect $(p<0.05)$ in increasing $\mathrm{RBC}, \mathrm{Hb}$, and $\mathrm{Ht}$. Therefore, the ethanol extract of katuk leaves can be a potential drug candidate for medicine in conditions where lower hematological parameters occur due to exposure to air pollution.
\end{abstract}

Key words: Air Pollution, Katuk Leaves, Hematology.

\section{INTRODUCTION}

Air is an essential factor in human life. Along with the development of cities and environmental transformation, air pollution due to human activities is also increasing. The causes of air pollution are mainly infrastructure development, industrial activities, and transportation. Infrastructure development, industrial activities, and transport lead to a decrease in air quality. Air pollution refers to releasing harmful substances or energy from other components into the air, mainly from human activities, causing the air quality to decrease to a certain level, not to fulfill its function. ${ }^{1}$ One of the most significant contributors to air pollution is vehicle smoke. The world health organization (WHO) estimates that $70 \%$ of the world's urban population has breathed polluted air through vehicle emissions, and $10 \%$ inhaled marginal air. Harmful gases from daily vehicle emissions may cause serious health in many countries, including Indonesia. Vehicle smoke contains chemicals that may affect metabolism in the human body. These chemicals include carbon monoxide (CO), nitrogen oxides (NOx), and Lead $(\mathrm{Pb}){ }^{1,2}$

$\mathrm{CO}, \mathrm{NOx}$, and $\mathrm{Pb}$ are dangerous pollutants to human health. These pollutants can be inhaled through breathing and enter the systemic blood vessels, affecting blood viscosity, thereby affecting several hematological parameters results. ${ }^{3}$ Lead in gaseous emission is very dangerous for health if it enters through the inhalation pathway in the lungs. The risk of $\mathrm{Pb}$ absorption through the inhalation system is higher (50-70\%) than if it enters through the ingestion system (5-10\%) into the body. The initial symptoms of lead poisoning are mild anemia, fatigue, sensitivity, dizziness, and paleness when blood $\mathrm{Pb}$ level increases from 60 to $120 \mu \mathrm{g} / \mathrm{dl} .{ }^{4}$ Lead poisoning will affect the occurrence of anemia and is characterized by a decrease in the number of red blood cells, hemoglobin, and hematocrit. Anemia results from increased production of aminolevulinic acid (ALA) and coproporphyrin in the hematopoietic system. Then it will decrease heme biosynthesis by causing aminolevulinic acid d-dehydratase (ALAD) and Fe-catalase activity. In general, the synthesis of heme becomes ineffective and subsequently becomes anemia. The effect of lead poisoning will influence the occurrence of anemia and is characterized by a decrease in the value of erythrocytes, hemoglobin $(\mathrm{Hb})$, and packed cell volume (PCV). ${ }^{5}$

Indonesia is an agricultural country with many medicinal herbs and plants that can be used as herbal ingredients. One of these plants is Katuk (Sauropus androgynus), which many Indonesians have known as a rich plant in nutrients and secondary metabolites. Katuk is rich in provitamin A which plays an essential role in eye health, reproductive

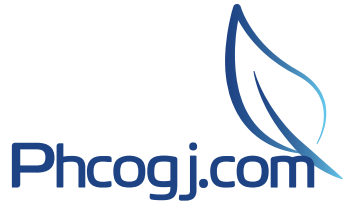

Cite this article: Siswanto B. The Effect of Ethanol Extract of Katuk Leaves (Sauropus androgynus) on Red Blood Cell Count (HR), Hemoglobin $(\mathrm{Hb})$, and Hematocrit $(\mathrm{Ht})$ of Rats Exposed to Emission. Pharmacog J. 2021;13(4): 860-865. 
health in humans and animals, vitamin $\mathrm{C}$ as a natural antioxidant, iron as a preventative for anemia. Katuk is considered a cheap, nutritious vegetable in various regions in Indonesia. According to Hegnauer, in 1964, katuk contains essential oils, sterols, saponins, flavonoids, triterpenoids, organic acids, amino acids, alkaloids, and tannins. ${ }^{6}$ Tannin compounds are antichelators that can bind metals that enter the blood vessels to prevent the bonding between $\mathrm{Pb}$ and hemoglobin. ${ }^{5}$

Papaverine and Prostaglandin, alkaloid compounds in katuk leaves, can work directly on blood vessels, smooth muscle, and heart muscle. These compounds can affect the dilatation of large blood vessels such as the aorta and arteries to reduce peripheral blood pressure. Besides that, papaverine can interact with red blood cells, especially on the ability of hemoglobin to bind oxygen. In addition, alkaloid compounds in this plant likely have the same effects as papaverine, and therefore, these alkaloids can be called papaverine-like compounds. ${ }^{7}$ The study was conducted to see the impact of katuk leaf ethanol extract on the hematological parameters of rats exposed to motorcycle emissions.

\section{MATERIALS AND METHODS}

The animal used in this study were 30 adult Rattus norvegicus strains with the weight range 150-300 g, divided into five groups (negative control (-), positive control (+), P1 extract $50 \mathrm{mg} / \mathrm{kg} \mathrm{BW,} \mathrm{P2} \mathrm{extract}$ $100 \mathrm{mg} / \mathrm{kg} \mathrm{BW}$, and P3 extract $200 \mathrm{mg} / \mathrm{kg}$ body weight). Experimental animals were adapted for seven days, and the treatment was conducted on the eighth day to the 16th day to the control (+) group and the treatment groups (P1, P2, and P3). According to the designated dosage, the ethanolic extract of katuk leaves was then given to P1, P2, and P3 groups. The control (+) group and the treatment groups were exposed to motorcycle emission in the morning and evening for 30 minutes/day, with the speed of the motorcycle was set to $30 \mathrm{~km} / \mathrm{hr}$. Then after the sixth day, all groups were drawn through the orbital vein, and then the blood plasma from all groups was prepared for laboratory examination.

This research implemented an experimental laboratory study using a complete random design (CRD). Research in the Department of Medical Laboratory Technology Banten Health Polytechnic. Data were collected and analyzed using one-way ANOVA.

\section{RESULTS}

There were five groups observed in this study, but the number of groups exposed to motorcycle smoke emission was four, namely $\mathrm{K}(+), \mathrm{P} 1, \mathrm{P} 2$, and $\mathrm{P} 3$. The hematological parameters analyzed in this study were red blood cell count (Table 1), hemoglobin level (Table 2), and hematocrit level (Table 3).

Table 1 shows the mean and SD obtained from the RBC analysis of all groups. It can be seen in table 1 that the highest number of red blood cells that the highest amount of RBC was $8.42 \pm 0.67$ million $/ \mathrm{mm} 3$, obtained from the P3 group, which was treated with $200 \mathrm{mg}$ ethanol extract per kg body weight. Table 1 shows the difference in red blood cell count (RBC) between the $\mathrm{K}(-)$ and $\mathrm{K}(+)$ groups. The $\mathrm{K}(+)$ group showed a lower RBC count compared to the $\mathrm{K}(-)$ group with a difference of $1.68 \pm(-0.07)$ million/mm3, and statistically, this shows a significant result, that is, $\mathrm{p}=0.00$. In addition, all the groups given the treatment were influential compared to the red blood cell count results in group $\mathrm{K}(+)$. Group $\mathrm{K}(+)$ showed the lowest effect compared to groups P1, $\mathrm{P} 2$, and $\mathrm{P} 3$.

Table 1: Analysis result of red blood cell count (million $/ \mathrm{mm}^{3}$ ).

\begin{tabular}{cccccc|}
\hline Rat No. & K(-) & K(+) & P1 & P2 & P3 \\
\hline 1 & 7.6 & 5.7 & 7.2 & 7.5 & 7.2 \\
2 & 7.4 & 5.7 & 6.5 & 7.8 & 8.5 \\
3 & 7.9 & 6.2 & 7.4 & 8.6 & 9.2 \\
4 & 7.2 & 5.5 & 7.8 & 8.4 & 8.7 \\
5 & 7.5 & 6.2 & 7.7 & 8.7 & 8.6 \\
6 & 7.4 & 5.6 & 7.5 & 7.8 & 8.3 \\
Mean \pm SD & $7.50 \pm 0.24$ & $5.82 \pm 0.31$ & $7.35 \pm 0.47$ & $8.13 \pm 0.49$ & $8.42 \pm 0.67$ \\
\hline
\end{tabular}

Note: $\mathrm{K}=$ control, $\mathrm{P}=$ treatment

Table 2: Hb profiles of all groups $(\mathrm{g} / 100 \mathrm{ml})$.

\begin{tabular}{cccccc|}
\hline Rat no. & K(-) & K(+) & P1 & P2 & P3 \\
\hline 1 & 11.5 & 6.4 & 12.3 & 13.4 & 13.7 \\
2 & 11.2 & 7.1 & 11.4 & 13.6 & 13.6 \\
3 & 10.7 & 7.4 & 12.4 & 13.5 & 14.7 \\
4 & 11.7 & 7.2 & 11.7 & 12.8 & 13.8 \\
5 & 11.9 & 7.6 & 12.3 & 13.7 & 14.6 \\
6 & 12.8 & 7.4 & 11.7 & 12.6 & 13.8 \\
Mean \pm SD & $11.6 \pm 0.71$ & $7.0 \pm 0.42$ & $12 \pm 0.42$ & $13.3 \pm 0.45$ & $14.0 \pm 0.48$ \\
\hline
\end{tabular}

Note: $\mathrm{K}=$ control, $\mathrm{P}=$ treatment

Table 3: Ht profiles of all groups (\%).

\begin{tabular}{|cccccc|}
\hline Rat no. & K(-) & K(+) & P1 & P2 & P3 \\
\hline 1 & 38.2 & 35.5 & 39.2 & 41.2 & 43.2 \\
2 & 37.5 & 35.7 & 38.6 & 38.7 & 44.5 \\
3 & 38.4 & 36.2 & 39.5 & 42.3 & 44.6 \\
4 & 36.6 & 35.4 & 37.6 & 43.4 & 45.6 \\
5 & 37.6 & 34.3 & 38.7 & 40.8 & 45.5 \\
6 & 38.7 & 34.5 & 37.4 & 40.6 & 44.2 \\
Mean \pm SD & $37.8 \pm 0.76$ & $35.3 \pm 0.73$ & $38.5 \pm 0.84$ & $41.2 \pm 1.60$ & $44.6 \pm 0.89$ \\
\hline
\end{tabular}

Note: $\mathrm{K}=$ control, $\mathrm{P}=$ treatment 
The study showed that the highest $\mathrm{Hb}$ level was obtained from the P3 group, resulting from $14.0 \pm 0.48 \mathrm{~g} / 100 \mathrm{ml}$. In this parameter, the higher the concentration of the extract, the higher the $\mathrm{Hb}$ level got. The overall results of the five groups observed in this study are shown in Table 2. The table also shows the difference in $\mathrm{Hb}$ level between the $\mathrm{K}(+)$ and $\mathrm{K}(-)$ groups with the distinction of $4.6 \pm 0.29 \mathrm{~g} / 100 \mathrm{ml}$, and statistically, this shows a significant result, which is $\mathrm{p}=0.00$.

In addition, all the groups given the treatment found that the results were adequate compared to the $\mathrm{Hb}$ group $\mathrm{K}(+)$ products. Group $\mathrm{K}$ (+) showed the lowest effect compared to groups P1, P2, and P3. The highest difference of $\mathrm{Hb}$ level was about seven $\mathrm{g} / 100 \mathrm{ml}$, between the $\mathrm{K}(+)$ group and the $\mathrm{P} 3$ group.

The profile of Ht was also observed from the hematological analysis of all groups. The effect of ethanol extract of katuk leaves on the Ht level was similar to the others two parameters observed in this study. The higher concentration of the extract, the higher the Ht level obtained. The highest percentage of Ht level among all treatment groups was showed by the P3 group, resulting from $44.6 \pm 0.89 \%$. The P1 group led the minor result with the result of $38.5 \pm 0.84 \%$. Table 3 shows the overall results obtained from all groups. Table 3 also shows the difference in $\mathrm{Ht}$ levels between the $\mathrm{K}(+)$ and $\mathrm{K}(-)$ groups with a difference of about $2.5 \%$. Statistically, this shows a significant result, which is $\mathrm{p}=$ 0.00 . Furthermore, the $\mathrm{K}(+)$ group also shows substantial differences compared to the $\mathrm{P} 1, \mathrm{P} 2$, and $\mathrm{P} 3$ groups in terms of the Ht levels obtained from the study. The $\mathrm{K}(+)$ group shows the lowest level of $\mathrm{Ht}$ among all groups treated with motorcycle emission, with the most significant difference with the $\mathrm{P} 3$ group of about $8 \%$.

\section{DISCUSSIONS}

Air pollution is the presence of one or more chemical, physical, or biological substances in the atmosphere in quantities that can endanger the health of living things. Air pollution mainly comes from motor vehicle emissions which contain carbon monoxide (CO), hydrocarbon gases, nitrogen oxides (NOx), particulates, sulfur dioxide, and lead $(\mathrm{Pb}){ }^{1,3}$ The emissions decrease air quality and may cause detrimental effects on health, especially $\mathrm{CO}$ and $\mathrm{Pb}$. These pollutants can come from the incomplete combustion of petroleum fuels that contain no oxygen in their molecular structure. About $70 \%$ of the $\mathrm{Pb}$ is also released from the explosion of powers. ${ }^{8}$

This study indicates that there is a significant reduction in the number of red blood cells in the $\mathrm{K}(+)$ group compared to the $\mathrm{K}(-)$ group. Group K (+) was exposed to motorcycle emissions without the ethanol extract treatment of katuk leaves. In contrast, the treatment groups (P1, $\mathrm{P} 2$, and P3) showed significant increases compared to the $\mathrm{K}(-)$ group, with the highest increase was observed in the P3 group with the result of $8.42 \pm 0.67 \mathrm{million} / \mathrm{mm}^{3}$. This group was treated with the ethanol extract of katuk leaves with a $200 \mathrm{mg} / \mathrm{kg}$ bodyweight concentration. The standard value of RBC count for rats ranges from 7.2-9.6 million/mm3. ${ }^{9}$ Based on this range, the results obtained from the treatment groups are still expected.

The increase in red blood cell count in the P3 group showed the ability of katuk leaves (Sauropus androgini) to reduce or prevent the effect of pollutants, especially $\mathrm{Pb}$, on hematological parameters. In katuk leaves, there are chemical compounds that can increase the levels of red blood cells. The results were in line with the previous study that katuk leaves have a benefit as an anti-anemia, and this study proves that at a dose of $200 \mathrm{mg} / \mathrm{kg}$ body weight, the extract shows the ability to increase red blood cells. ${ }^{10,11}$

Previous studies also found that papaverine and prostaglandin alkaloids in katuk leaves can work directly on blood vessels, smooth muscle, and cardiac muscle. These compounds contribute to enlarging blood vessels such as the aorta and arteries and reduce blood pressure. In addition, papaverine can interact with red blood cells, especially in the ability of heme protein to bind oxygen. Papaverine has an affinity for hemoglobin for oxygen. The smoke emissions from the motorcycle, which contain $\mathrm{CO}$, may increase the affinity of hemoglobin by reducing its relationship with oxygen. Therefore, the blood flow decreases, and the cell's ability to transport oxygen to the whole body become lower. This condition stimulates the formation of eripoetin for the construction of the new red blood cells. The building will continue until the oxygen demand from the tissue is fulfilled. Since the oxygen level increases, the Hb will also be synthesized in red blood cells, and therefore the hemoglobin level will increase. ${ }^{7,12}$

On the $\mathrm{K}(+)$ group, the average hemoglobin level is lower. This situation occurs due to the effect of pollutants from motorcycle emissions, especially $\mathrm{Pb}$ and $\mathrm{CO}$ inhaled by the rats. This condition interferes with the hematopoiesis function, indicated by the lower hemoglobin level compared to the average level. Lead $(\mathrm{Pb})$ inhaled by humans every day will be absorbed and stored in the blood and then circulated by blood vessels throughout the body. This metal accumulation may cause a chronic condition, and if the body is continuously exposed to this pollutant to a certain degree, the poisoning can occur. Lead poisoning at an early level causes irritability, lethargy, muscle weakness, and constipation. If the group becomes higher, it may damage the liver, kidney, stomach and maybe causing abnormal pregnancy. ${ }^{13}$

Lead poisoning will affect the occurrence of anemia and is characterized by a decrease in the number of red blood cells, hemoglobin, and hematocrit. Anemia results from increased production of aminolevulinic acid (ALA) and coproporphyrin in the hematopoietic system. Then it will decrease heme biosynthesis by causing aminolevulinic acid d-dehydratase (ALAD) and Fe-catalase activity. In general, heme synthesis becomes ineffective. ${ }^{5}$ An increase in hemoglobin $(\mathrm{Hb})$ in these three treatment groups compared to the $\mathrm{K}(+)$ and $\mathrm{K}(-)$ groups indicates the ability of katuk leaves to reduce or prevent the effects of motorcycle smoke emissions since the katuk leaves contain the chemical compounds that act as an anti-anemia. ${ }^{11}$

According to Suprayogi (2000), katuk leaves contain several valuable substances such as carbohydrates, proteins, fats, iron, phosphorus, and vitamins ( $\mathrm{A}, \mathrm{B}$, and $\mathrm{C}$ ). Besides that, katuk leaves also contain several active compounds such as saponins, tannins, flavonoids, steroids, polyphenols, prostaglandins, and papaverines. Tannin compounds are antichelator compounds that can bend metal into blood vessels to prevent the bond between $\mathrm{Pb}$ and Hemoglobin from occurring. ${ }^{7}$

This study also showed the effect of ethanol extract of katuk leaves on hematocrit level. The results showed significant increases in the treatment groups (P1, P2, and P3), with the highest yield was obtained from the P3 group. According to Smith and Mangkowiedjojo, the traditional value of normal hematocrit levels in mice ranges from 39 to $47 \%{ }^{9}$ So this research is in line with previous findings.

On the other hand, lead poisoning can interfere with hemoglobin $(\mathrm{Hb})$ synthesis by inhibiting the conversion of delta-aminolevulinic acid (ALAD) to porphobilinogen. Lead poisoning inhibits the cooperation of $\mathrm{Fe}$ (iron) into protoporphyrin IX to form $\mathrm{Hb}$. In other words, the synthesis of hemoglobin $(\mathrm{Hb})$ becomes less effective, which causes anemia characterized by a decrease in the value of red blood cells, hemoglobin, and hematocrit. ${ }^{14}$ In the treatment group, the increase in hematocrit levels was due to the formation of erythrocytes. Increased levels of hematocrit are influenced by factors that also affect the number of erythrocytes and cell size. The hematocrit level also varies significantly between individuals and is influenced by the degree of body activity. In the treatment groups of $\mathrm{P} 2$ and $\mathrm{P} 3$, the Ht levels were still within the normal range. 


\section{REFERENCES}

1. Tasir, Yudha Adi: Pengaruh Usia Kendaraan Terhadap Emisi Karbon Monoksida (Co) Dan Hidrokarbon (Hc) Kendaraan Bermotor Di Kota Bengkulu (2017)

2. Malaka,Tan dan Meiri Iryani: Hubungan Kadar Timbel dalam Darah dengan Kadar Hemoglobin dan Hematokrit pada Petugas Pintu Tol Jagorawi. Jurnal kesehatan Masyarakat Nasional Vol. 6, No.1, Agustus (2011).

3. Acikayudia, Arantsa, Tulus Ariyadi, Andri Sukeksi: Gambaran Indeks Eritrosit Pada Sopir Bus Jurusan Penggaron-Mangkang di Terminal Penggaron Semarang. KTI D III Analis Kesehatan Fakultas IImu Keperawatan dan Kesehatan. Universitas Muhammadiyah Semarang (2017).

4. Lathifah, N Syakbanah: Hubungan Kadar Pb Udara Dan Karakteristik Responden Terhadap Kadar Pb Darah Tukang Becak Di Gresik. Jurnal Kesehatan Lingkungan Vol. 10, No.1 Januari. 92-103(2018).

5. Dwi, A Wijayanti, A. Fumia Maria dan S. Nur Khasanah: The Effect Of White Turmeric (Curcuma Albn) Extract On The Values Of $\mathrm{Hb}$ (Hemoglobin), Pcv (Packed Cell Volurne), Total And Differential Counts Of Leucocytes Of Rat Exposed With The Gas Emission Of Motorcycle. Jurnal Sain Vet Vol. 29, No.1(2011).

6. Santoso, Urip: Katuk, Tumbuhan Multi Khasiat. Januari (2014).
7. Wandi, N Bahar: Pengaruh Pemberian Ekstrak dan Fraksi Daun Katuk (Sauropus androgynus (L.) Merr) terhadap Gambaran Hematologi pada Tikus Putih Laktasi. Skripsi IPB (2011).

8. Ismiyati, D. Marlita, and D. Saidah: Pencemaran Udara Akibat Emisi Gas Buang Kendaraan Bermotor," J. Manajemen. Transportasi \& Logistik. Vol. 01, no. 03.241-248 (2014).

9. Ayu, D Widyastuti: Profil Darah Tikus Putih Wistar pada Kondisi Subkronis Pemberian Natrium Nitrit," J. Sain Veteriner. Vol. 31, no. 2. 201-215 (2009)

10. Silalahi, Marina dan Hertina Silaban: Studi Literatur: Sauropus Androgynus (Pemanfaatan Dan Toksisitasnya). Jurnal Kesehatan Manarang. Vol.5, No.2, 72-79. Desember (2019).

11. Hasimun, Patonah, W. Aligita, dan I. Nopitasari: Anti Anemic and Analgesic Activity of Sauropus Androgynous L Merr on Female Mice Model. Int. J. Pharm. Phytopharm. Res., vol. 8, no. 1. 98-102 (2018).

12. J. E. Guyton, A. C., Hall, Buku Ajar Fisiologi Kedokteran, 12th ed. Jakarta, Indonesia: EGC, (2014).

13. Gusnita, Desi: Pencemaran Logam Berat Timbal (Pb) Di Udara Dan Upaya Penghapusan Bensin Bertimbal. Berita Dirgantara. Vol.13, No.3. 95-101. September (2012).

14. Kustiningsih, Yayuk, N. Fitriyanti Thomas, and Nurlailah: Kadar Logam Timbal (Pb) Dalam Darah Penjual Klepon. Med. Lab. Technol. J., vol. 3, no.2, 47-52 (2017). 


\section{GRAPHICAL ABSTRACT}

The Effect Of Ethanol Extract Of Katuk Leaves (Sauropus Androgynus) On Red Blood Cell Count (Hr), Hemoglobin (Hb), And Hematocrit (Ht) Of Rats Exposed To Emission

Katuk Leaves (Sauropus Androgynus)

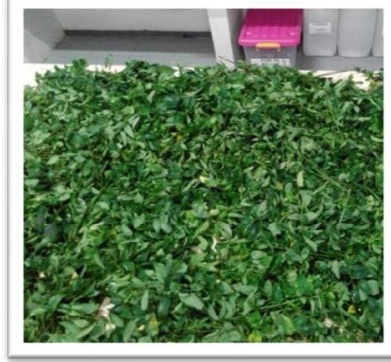

Squeeze



8

Weigh the rats

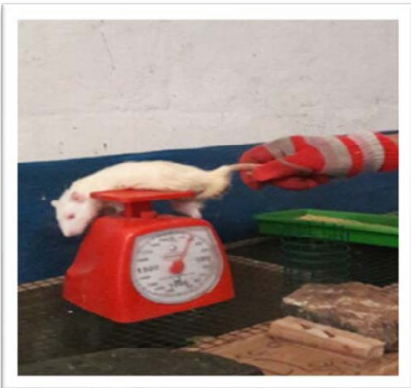

Weighing
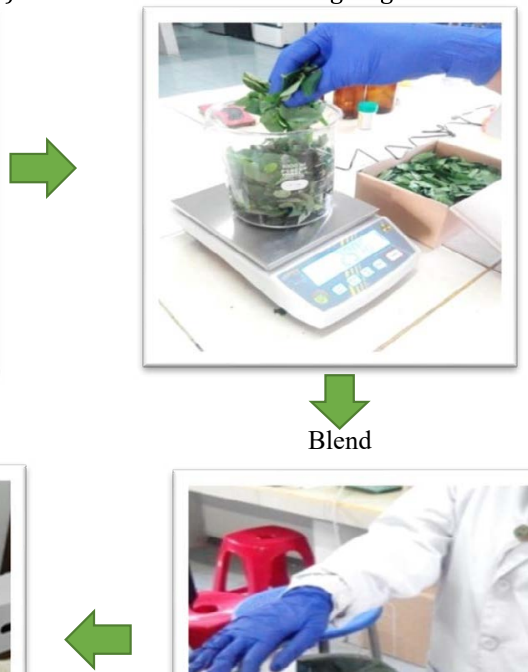

Blend

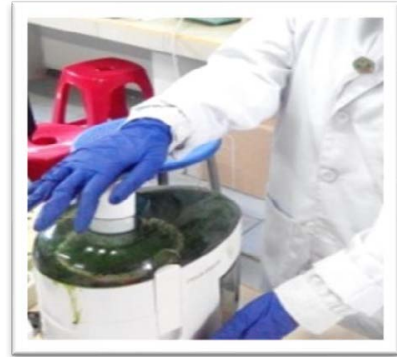

Adaptation of mice in the experimental
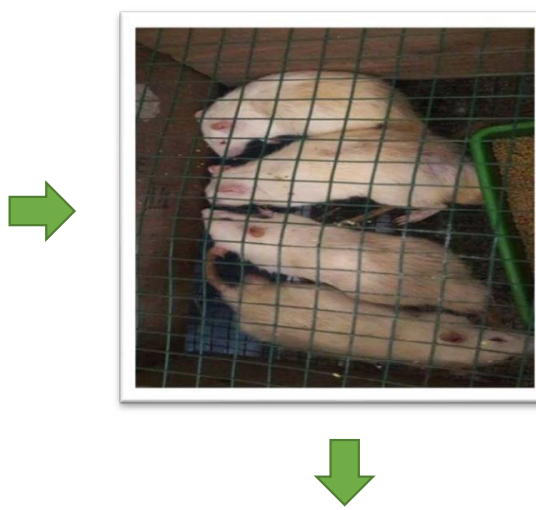

Giving katuk leaves extract to rats (Sauropus androgynus)

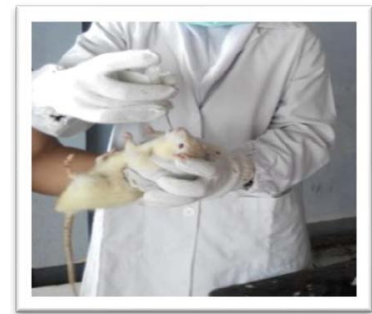

\section{SUMMARY}

Ethanol extract of katuk leaves significantly affects hematological parameters, including red blood cell count, hemoglobin, and hematocrit in rats treated with motorcycle emissions. 


\section{ABOUT AUTHORS}

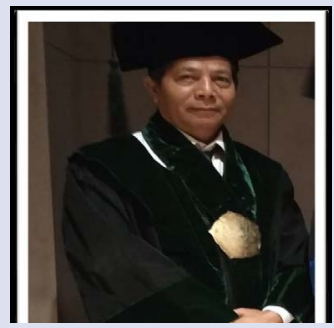

Budi Siswanto, Lecturer, Researcher in the Department of Medical Laboratory Technology, Health Polytechnic, Ministry of Health, Banten. Specialization in the field of physiology and observers of the use of herbal plants. Has published several research papers on the Utilization of Medicinal Plants as Herbs and Phlebotomy practice module books.

Cite this article: Siswanto B. The Effect of Ethanol Extract of Katuk Leaves (Sauropus androgynus) on Red Blood Cell Count (HR), Hemoglobin $(\mathrm{Hb})$, and Hematocrit $(\mathrm{Ht})$ of Rats Exposed to Emission. Pharmacog J. 2021;13(4): 860-865. 